neofilolog

Czasopismo Polskiego Towarzystwa Neofilologicznego

ISSN 1429-2173, 2019, NR 53/2, 263-280

http://dx.doi.org/10.14746/n.2019.53.2.8

http://poltowneo.org/

Ewa Pórtorak

Uniwersytet śląski, Katowice-Sosnowiec https://orcid.org/0000-0002-3179-5681 ewa.poltorak@us.edu.pl

\title{
PODEJŚCIE DO BŁĘDU W NAUCE JĘZYKÓW OBCYCH - PERSPEKTYWA UCZNIA
}

\section{The role of errors in foreign language learning - the leamer's perspective}

The aim of the paper is to reflect on the problem of errors in the foreign language teaching-learning process from the learner's perspective. The author proposes to investigate learners' beliefs and opinions related to the role of errors in foreign language learning process. The problem will be discussed in the context of the teaching-learning process of French as a second language to adult beginners. The study was conducted among the students of the Institute of Romance Languages and Translation Studies at the University of Silesia. The data collected was analysed and divided into subject categories in order to provide an overall view of students' beliefs and attitudes towards errors.

Keywords: foreign language teaching-learning process, errors, errors correction, feedback, learners' beliefs and attitudes towards errors

Słowa kluczowe: proces nauczania-uczenia się języków obcych, błąd językowy, korekta błędów, informacje zwrotne, przekonania ucznia

\section{Wstęp}

Błąd stanowi jeden z nieodłącznych elementów procesu nauczania/uczenia się, w tym również kształcenia językowych kompetencji komunikacyjnych. I choć na 
przestrzeni lat podejście do błędu na lekcji języka obcego ulegało istotnym przemianom (por. Germain, 1993; Larruy, 2003, Lewicka-M roczek, 2009), we współczesnych koncepcjach glottodydaktycznych panuje raczej jednomyślne przekonanie, iż błąd jest nie tylko naturalnym elementem uczenia się, ale i cennym źródłem informacji na temat właściwości oraz przebiegu tego procesu (por. Tagliante, 2005; Hadji, 2012). M ożna powiedzieć, że w pewnym sensie błąd jest traktowany jako ważny element nauki, wspomagający ucznia w procesie weryfikowania hipotez na temat funkcjonowania języka docelowego i konstruowania znaczeń nowo poznawanych struktur językowych. Powyższe przekonanie zasadniczo podzielają zarówno teoretycy nauczania, jak i nauczyciele. Czy jednak, i na ile, opinia ta jest podzielana przez samych uczących się? Postawa, jaką przejawiają wobec błędu, jak i sama akceptacja jego obecności w procesie uczenia się wydają czynnikami, które mogą mieć decydujący wpływ na skuteczność korekty błędów językowych, czy też w szerszym wymiarze, na wszelkiego rodzaju działanie o charakterze ewaluacyjnym. Tymczasem wstępna analiza literatury przedmiotu, szczególnie z zakresu badań poświęconych trudnościom w uczeniu się języków obcych oraz nasze własne obserwacje pokazują, że poglądy uczniów inauczycieli w interesującej nas kwestii nie są do końca zbieżne. Zjednej strony sytuacja ta może przyczyniać się do pogłębiania już istniejących barier w nauce języka lub powstawania nowych, a z drugiej, obniżać skuteczność korekty językowej.

Celem niniejszego artykułu będzie podjęcie spojrzenie na błąd w nauce języków obcych z perspektywy uczących się. Zaproponowane refleksje zostaną osadzone w kontekście kształcenia językowych kompetencji komunikacyjnych na poziomie początkującym, a punktem odniesienia dla przedstawionych w drugiej części artykułu badań będzie proces nauczania/uczenia się języka francuskiego jako (co najmniej) drugiego języka obcego przez osoby dorosłe na poziomie kształcenia uniwersyteckiego.

\section{Błąd na lekcji języka obcego - zarys problematyki}

Liczba publikacji poświęconych problematyce błędu językowego świadczy o niemałej popularności interesującego nas zjawiska wśród współczesnych badaczy. Jak jednak zauważa Zawadzka (2004), pomimo tak dużego zainteresowania pojęcie błędu językowego nie doczekało się jednoznacznej definicji, szczególnie w piśmiennictwie glottodydaktycznym.

Na brak terminologicznej jednomyślności w odniesieniu do omawianego konceptu niewątpliwie wpływa zwyczaj definiowania błędu przez pryzmat normy językowej, która sama w sobie jest pojęciem niejednoznacznym i która do dziś stanowi przedmiot ożywionych dyskusji językoznawczych (por. 
Rey, 1974; Bedard, 1983; Bedard i Maurais, 1983; M iodek, 2001; Siouffi i Steuckardt, 2007; Bertrand i Schaffner, 2010; Zbróg, 2018). Nie wchodząc w szczegóły, których wyczerpująca analiza wykracza poza ramy niniejszej publikacji, należy nadmienić, że wśród współczesnych badaczy panuje w miarę zgodna opinia, iż komunikat językowy powinien być oceniany nie tylko z perspektywy swojej poprawności, tj. zgodności ze zbiorem reguł przewidzianych przez system danego języka (mowa o tzw. normie preskryptywnej, wzorcowej, wysokiej, estetycznej czy też Normie), lecz także z perspektywy swojej akceptowalności, tj. dostosowania do parametrów wypowiedzi takich jak kontekst, status rozmówcy czy też rodzaj użytego kanału komunikacyjnego (mowa o tzw. normie bądź normach użytkowych). Znaczenie tak pojmowanej normy językowej podkreśla między innymi Miodek (2001: 73), tłumacząc, że ma ono „znaczenie nie tylko teoretyczne, ale przede wszystkim praktyczne. Nawiązują do niego - świadomie lub nieświadomie - wszyscy użytkownicy języka, gdy zaczynają się zastanawiać nad wyborem odpowiednich środków wyrażenia myśli. Przestrzeganie normy jest jednym z czynników warunkujących funkcjonalną sprawność wypowiedzi."

Przywołane podejście do normy językowej uwidacznia się w definicjach błędu językowego, przez który zazwyczaj rozumie się "niezamierzone przez mówiącego odchylenie od reguł przewidzianych przez system danego języka lub od [obowiązujących] w ramach tego systemu [norm użytkowych]" (Szulc, 1984: 33). W konsekwencji zwykło się wyodrębniać dwa zasadnicze rodzaje błędów językowych:

- $\quad$ tzw. błędy systemowe (errors), sytuujące się na poziomie kompetencji,

- oraz błędy sytuujące się na poziomie użycia języka, czyli tzw. omyłki (mistakes) (Corder, 1967 [1980a]),

choć, jak podkreślają niektórzy badacze, ich rozróżnienie w praktyce może być dosyć trudne lub wręcz niemożliwe (por. Corder 1967, 1971 [1980]; Besse, Porquier, 1991).

Podobną koncepcję błędu odnaleźć można również w Europejskim systemie opisu kształcenia językowego (2003), który stanowi jeden z podstawowych dokumentów, określających podstawowe założenia i cele europejskiej polityki językowej. I tak, autorzy ESOKJ traktują błędy jako „przejaw 'interjęzyka', czyli uproszczonej, niedoskonałej wersji kompetencji docelowej, która rozwinęła cechy odbiegające od normy obowiązującej w języku drugim", natomiast omyłki utożsamiają z sytuacjami, w których uczący się "nie stosuje we właściwy sposób posiadanej kompetencji" (2003: 134).

Analiza zjawiska błędu w kontekście nauki języków obcych wymaga odniesienia nie tylko do różnorodnych aspektów szeroko rozumianej normy językowej, tak jak to zasygnalizowano powyżej, lecz także uwzględnienia czynników wynikających ze specyfiki procesu uczenia się języka obcego, jak i dynamicznego charakteru rozwoju kompetencji językowych. Mowa tu o tzw. normie 
glottodydaktycznej, rozumianej ogólnie jako „zbiór normatywnych parametrów wyznaczonych dla treści językowych na danym etapie nauczania, uwzględniającym czynniki rozwojowe, [interjęzyk] ucznia, warunki nauczania itp." (por. Zawadzka, 2004: 251). Takie ujęcie normy pozwala na podkreślenie jej stopniowalności oraz zmienności w odniesieniu do produkowanych komunikatów językowych. W konsekwencji, obecność normy glottodydaktycznej w kształceniu językowym pozwala na wprowadzenie w miarę obiektywnego kryterium oceny osiągnięć ucznia uwzględniającego jego aktualne potrzeby i umiejętności językowe (por. Chomicz-Jung, 1990). Z takim rozumieniem normy możemy się spotkać między innymi w opisach poszczególnych poziomów kompetencji, proponowanych przez autorów wspominanego już wcześniej ESOKJ (2003).

Odwołując się do przywołanej koncepcji normy glottodydaktycznej, pozostaje doprecyzować, że w aktualnych metodach nauczania/uczenia się języków obcych przez błąd rozumie się nie tyle odchylenie od reguł systemowych czy użytkowych, ile odstępstwo od „pewnego założonego do opanowania na określonym etapie nauczania kwantum wiadomości i umiejętności" (Chomicz-Jung, 1985: 156).

Reasumując nasze dotychczasowe rozważania, można powiedzieć, że w nauce języka obcego mogą współwystępować co najmniej dwa zasadnicze typy błędów:

- błąd stricte językowy oznaczający każde odstępstwo od ogólnie przyjętej normy językowej oraz

- błąd stricte glottodydaktyczny, odnoszący się do jakiejkolwiek formy, która, zdaniem nauczyciela, odbiega od przewidzianych dla danego etapu założeń programowych.

O ile formalnej ocenie powinien podlegać tylko drugi zwymienionych rodzajów błędu, o tyle, w celu uniknięcia utrwalania się niepoprawnych form językowych obydwa typy błędów powinny być przedmiotem korekty ze strony nauczyciela (por. Chomicz-Jung, 1985, 1990; Zawadzka, 2004). Warto przypomnieć, że choć przydatność tej ostatniej nie zawsze była przedmiotem konsensu wśród glottodydaktyków (por. Germain, 1993; Cuq i Gruca, 2005; Tagliante, 2005; Tardieu, 2008), to obecnie panuje raczej jednomyślne przekonanie co do pozytywnego wpływu korygujących informacji zwrotnych (ang. feedback) na rozwój umiejętności ucznia i mało kto kwestionuje ich użyteczność (zestawienia aktualnych teorii na temat roli błędu oraz informacji zwrotnych w procesie glottodydaktycznym dokonuje m. in. Tagliante 2005; Huver i Springer, 2011; Pawlak, 2012; Półtorak, 2015, 2018). Nie dziwi również fakt, że sama korekta językowa - wpisująca się w szerszy kontekst procesu ewaluacji, jak i analiza czynników warunkujących jej skuteczność stanowią przedmiot zainteresowania wielu współczesnych glottodydaktyków (por. Lyster i Ranta, 1997; M ory, 2004; Ellis, 2009; Huver, Springer, 2011; Pawlak 2012, 2013). Większość z nich podziela zdanie, że „korekta błędnych wypowiedzi uczniów w klasie językowej stanowi 
sposobność do nauki. Popełnianie błędu może potencjalnie stanowić okazję, aby się czegoś nauczyć" (Larsen-Freeman, 2003, w Pawlak, 2013: 307). Jednak jednym z istotnych czynników warunkujących powodzenie tego procesu wydaje się być sama postawa uczących się wobec otrzymywanej korekty językowej, jaki błędu jako takiego. Wstępna analiza badań poświęconych trudnościom w uczeniu się języków obcych (por. Arnold, 2006; Komorowska, 2011; Smuk, 2016) oraz własne obserwacje doprowadziły nas do refleksji, że uczącym się, zwłaszcza w dorosłym wieku, trudno zaakceptować obecność błędu w procesie uczenia się i w mniej lub bardziej świadomy sposób wykorzystywać go w rozwijaniu własnych umiejętności językowych. Postanowiliśmy zatem bliżej przyjrzeć się postawie uczących się wobec błędu i poznać ich przekonania na temat jego roli w nauce języków obcych.

\section{Rola błędu w kstałceniu językowych kompetencji komunikacyjnych z perspektywy uczących się - wyniki badań własnych}

\subsection{Cel badań}

Bezpośrednią inspiracją do przeprowadzania badań były wcześniejsze obserwacje problemów, jakie napotykają osoby dorosłe rozpoczynające naukę kolejnego języka obcego na poziomie kształcenia akademickiego oraz analizy wyników pilotażowych ankiet na temat trudności w nauce drugiego/kolejnego języka obcego, jakie przeprowadziliśmy w latach 2016-2018 wśród studentów pierwszych lat kierunków neofilologicznych Uniwersytetu Śląskiego. Badania te jednoznacznie pokazały, że zdaniem respondentów jedną z głównych barier w rozwijaniu umiejętności w drugim/kolejnym języku obcym stanowi zjawisko lęku językowego i towarzyszące mu poczucie lęku przed popełnieniem błędu (Półtorak, 2019 [w druku]). Popularność tej ostatniej odpowiedzi wydała nam się na tyle interesująca, że postanowiliśmy przyjrzeć się bardziej szczegółowo zagadnieniu błędu językowego z perspektywy uczących się. W związku z tym celem badań omówionych w ramach niniejszego artykułu stała się próba wglądu w opinie uczących się na temat roli błędu w nauce języków obcych. Nasze dociekania badawcze zawęziliśmy do najbardziej interesującego nas kontekstu badawczego, jakim jest proces nauczania/uczenia się języka francuskiego jako (co najmniej) drugiego języka obcego przez osoby dorosłe na poziomie kształcenia uniwersyteckiego. Główny cel badań doprowadził do sformułowania następujących szczegółowych pytań badawczych:

1) W jaki sposób dorośli uczący się podchodzą do zjawiska błędu językowego w nauce drugiego języka obcego (w naszym przypadku języka francuskiego)?

2) Czy i w jaki sposób dorośli u czący się wykorzystują swoje błędy językowe w pracy nad rozwijaniem własnych umiejętności w zakresie nauki drugiego języka obcego (w naszym przypadku języka francuskiego)? 


\subsection{Próba badawcza}

Badanie zostało przeprowadzone wśród studentów Wydziału Filologicznego uŚ w roku akademickim 2017/2018. Docelowa grupa badawcza liczyła 62 osoby (w tym 50 kobiet i 12 mężczyzn) rozpoczynające naukę języka francuskiego jako (co najmniej) drugiego języka obcego na studiach I stopnia na specjalności: język francuski i język angielski z programem tłumaczeniowym. W celu uściślenia warto dodać, że w badaniu wzięły udział osoby dorosłe (średnia wieku wyniosła 20 lat), dla których językiem ojczystym był polski i które w momencie rozpoczynania nauki na studiach posługiwały się dobrą lub bardzo dobrą znajomością angielskiego (pierwszego języka obcego). Dla większości grupy (42 osoby) francuski był trzecim językiem obcym, a dla pozostałych 20 osób - drugim. Wśród tych ostatnich, 3 osoby uczyły się wcześniej francuskiego jako drugiego języka obcego w gimnazjum, a 5 - w liceum. Zważywszy na cel badań wcześniejsza nauka francuskiego nie stanowiła czynnika mogącego zakłócić pozyskane wyniki i w związku z tym grupa tzw. fałszywych poczatkujących nie była wyłączona z badań.

Badanie zostało przeprowadzone po I semestrze nauki języka francuskiego (poziom A1/A1+według ESOKJ) i odnosiło się przede wszystkim do zajęć przeprowadzonych w ramach modułu praktycznej nauki języka.

\subsection{Narzędzia badawcze}

Narzędziem, które posłużyło do zebrania materiału badawczego był kwestionariusz, zawierający wyłącznie pytania o charakterze otwartym, na które respondenci odpowiadali pisemnie. Wykorzystanie tego rodzaju techniki pozyskiwania danych miało na celu zapewnienie uczestnikom badania możliwości pogłębionej refleksji nad zaproponowaną problematyką badawczą. Choć z metodologicznego punktu widzenia wybór takiego rozwiązania może nieść pewne ograniczenia (sytuujące się między innymi na poziomie analizy pozyskanych informacji, które w znacznej mierze opierają się na danych introspekcyjnych), to jednak jego zastosowanie pozostawia respondentom większą swobodę co do treści oraz formy udzielanych odpowiedzi niż może to mieć miejsce w przypadku technik zamkniętych (por. Wilczyńska, M ichońska-Stadnik, 2010). Ponadto sama tematyka badawcza i chęć wglądu w przekonania respondentów leżące u źródeł interesującej nas kwestii zadecydowały o wyborze takiej formy kwestionariusza.

Łącznie zadano 5 pytań, stopniując stopień ich uszczegółowienia:

[P1] Jakq rolę Pana/Pani zdaniem może pełnić błąd językowy w nauce języka obcego? 
[P2] W przypadku nauki języka francuskiego, jaka jest Pan/Pani postawa wobec popełnianych przez siebie błędów?

[P3] Czy i w jaki sposób wykorzystuje Pan/Pani swoje błędy językowe w rozwijaniu swoich umiejętności w zakresie języka francuskiego?

[P4] Na jakie błędy językowe popełniane przez siebie na zajęciach z języka francuskiego zwraca Pan/Pani szczególnq uwagę i dlaczego?

[P5] Co uważa Pan/Pani za główną przyczynę popełnianych przez siebie błędów na zajęciach z języka francuskiego?

Zanim przejdziemy do analizy i omówienia odpowiedzi respondentów, chcielibyśmy zwrócić uwagę na dwie kwestie dotyczące przyjętego sposobu prezentacji wyników. Po pierwsze, w celu ułatwienia interpretacji pozyskanych danych zebrany materiał badawczy został wstępnie podzielony na różne kategorie tematyczne, które zostały wyodrębnione na podstawie analizy udzielonych przez respondentów odpowiedzi. Dla każdej kategorii obliczyliśmy następnie wynik procentowy, odnoszący się do liczby osób, których odpowiedzi zostały przyporządkowane do poszczególnych kategorii. Dzięki temu zyskaliśmy możliwość ukazania ogólnych tendencji zarysowujących się w odpowiedziach udzielanych przez studentów.

Należy również zaznaczyć, że otwarty charakter pytań umożliwił ankietowanym formułowanie wypowiedzi wielowątkowych, co z kolei wpłynęło na możliwość pojawienia się więcej niż jednej kategorii tematycznej w ramach jednej udzielonej odpowiedzi. W związku z tym suma podanych wyników procentowych dla odpowiedzi udzielonych w ramach poszczególnych pytań nie zawsze jest równa 100.

\subsection{Prezentacja wyników}

\subsubsection{Ogólna postawa wobec błędu językowego}

Analizując odpowiedzi respondentów na temat roli błędu w nauce języków obcych, można powiedzieć, że ich zdanie nie jest jednorodne, choć, jak pokazują dane przedstawione na wykresie nr 1, wśród ankietowanych dominuje ogólnie negatywne nastawienie do błędu.

Szczegółowa analiza pozyskanych danych pozwala zauważyć, że ankietowani studenci postrzegają błąd głównie przez pryzmat procesu oceniania taka opinia powtarza się w odpowiedziach 25 osób [40\%]. Ta grupa powołuje się często na argument, że „błąd służy nauczycielom przede wszystkim do oceniania wypowiedzi" (S13; S22; S27; S39; S43; S59). Nie obce są także zdania wśród ankietowanych, że błąd nie powinien w ogóle być przedmiotem zainteresowania i powinien być za wszelką cenę eliminowany z nauki języka obcego. Takiej odpowiedzi udzieliło 20 osób [32\%], tłumacząc między innymi, że: 
Myślę, że błędy moga byćszkodliwe i nie powinno się im poświęcać uwagi. (S28; S41)

Mój krepetytor $z$ angielskiego ciagle mi powtarzał, że nie można popełniaćbłędów, jak się chce do czegoś dojść w życiu. (S34)

Bład nie powinien odgrywać żadnej roli w nauce języków, bo jak się chce dobrze znać język, to się nie powinno popełniać błędów i trzeba je eliminować. (S51).

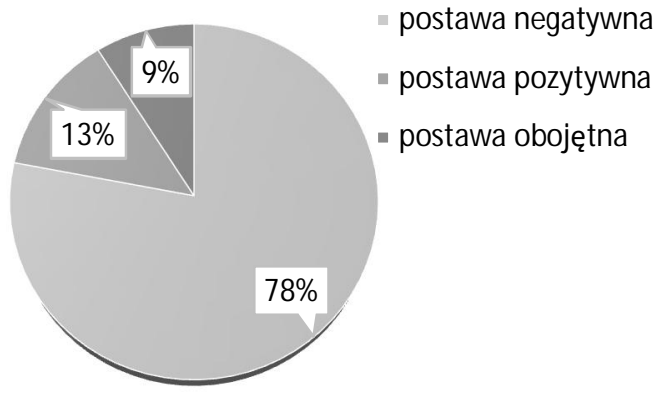

Wykres 2: Ogólna postawa wobec błędu językowego wśród ankietowanej grupy studentów [\%].

Co więcej, odpowiedzi niektórych studentów (8 osób) jasno wskazywały, że percypują błąd przede wszystkim w kategoriach przeszkody, utrudniającej skuteczną naukę języka docelowego, o czym świadczyły między innymi takie wypowiedzi jak:

M oim zdaniem, błędy stanowiq przeszkodę na drodze do skutecznej nauki języka. (S29) lub

Uważam, że błędy szkodzq dobrej znajomości języków obcych (S11).

Dla czterech osób [6\%] błąd językowy jest tożsamy z niepełnymi umiejętnościami językowymi:

Bład jest zjawiskiem negatywnym, a popełnianie błędów źle świadczy o czyichś kompetencjach językowych. (S54)

Bład językowy sygnalizuje, że dana osoba jest niekompetentna. (S12)

Popełnianie błędów wpływa negatywnie na naukę języka i uniemożliwia jego perfekcyjne opanowanie. (S7)

Tylko 8 ankietowanych [13\%] wskazało na pozytywną rolę błędu w kształceniu językowym, postrzegając go bądź jako wskazówkę, tego co jeszcze wymaga nauki lub poprawy:

Błą może służyć do poprawienia znajomości jakiegoś materiału. [S8], 
bądź jako element strategii uczenia się:

Robienie błędów pozwala lepiej zapamiętać, jak działa język. [S55].

\section{4. 2. Opinie na temat roli błędu językowego w nauce języka francuskiego}

Kolejne pytania kwestionariusza pozwoliły zawęzić kontekst wybranego problemu badawczego do procesu nauczania/uczenia się języka francuskiego jako (co najmniej) drugiego języka obcego.

W odpowiedziach na pytanie dotyczące postawy wobec popełnianych błędów na zajęciach języka francuskiego ([P2] W przypadku nauki języka francuskiego, jaka jest Pan/Pani postawa wobec popełnianych przez siebie błędów?) zauważyć można dominację dwóch skrajnych tendencji w udzielonych przez respondentów odpowiedziach:

- z z jednej strony część studentów [19 osób] w ogóle nie zwraca uwagi na popełniane błędy, gdyż w ich opinii nie stanowią one przydatnego elementu nauki, np.:

Raczej nie zwracam uwagi na popetniane przez siebie błędy, bo one mi tylko przeszkadzaja w nauce. [S33]

Staram się skupiać tylko na poprawnych formach, błędne niczemu nie służq. [S54])

- z z drugiej zaś strony część osób [26] upatruje w popełnianych przez siebie błędach źródła stresu i lęku, np.

Boję się popełnić błąd i wolę nie ryzykować, jak czegoś nie jestem pewien. [S58]

Boję się popełniać błędy i każdy kolejny błąd paraliżuje mnie jeszcze bardziej przed używaniem tego języka [francuskiego]. [S14]

i często przypisuje im współwystępowanie innych negatywnych emocji, np.:

Błędy wywołujq u mnie poczucie wstydu, szczególnie kiedy wiem, że inni patrzq na mnie, kiedy nauczyciel mnie poprawia. [S19]

bądź nieprzyjemnych reakcji organizmu:

Ściska mnie w gardle i zaczyna mi drżeć głos, jak cokolwiek zaczynam mówić po francusku. Powtarzam sobie w myślach, żeby się nie denerwować i to zazwyczaj pomaga. [S3] 
Jak chce coś powiedzieć po francusku, to strach przed popełnieniem błędów jest tak duży, że blokuje wszystkie moje myśli i nie jestem w stanie ich zebrać. [S15].

Wśród odpowiedzi udzielonych przez tę ostatnią grupę studentów nierzadko pojawiają opinie wskazujące na preferowaną przez nich niebezpieczną postawę unikową: aby nie narazić się na popełnianie błędów, starają się wystrzegać wypowiedzi, których nie są pewni i które mogłyby się okazać chybione, np.:

Jak nie wiem, czy dobrze coś zapamiętałam, to siedzę cicho, bo boję się popełnić błąd. [S2]

Frustruje mnie to, że w większości przypadków znam odpowiedź, a mimo to nic nie mówię, bo boję się, że popetnię błąd [S47]

Taka postawa może doprowadzić do uruchomienia mechanizmu błędnego koła: brak testowania nowych struktur językowych może w zdecydowany sposób ograniczyć sytuacje, w których uczący się będzie mógł swobodnie partycypować, co z kolei może spowolnić wszelki postęp językowy, a nawet wpłynąć demotywująco na dalszą naukę danego języka.

Zebrany materiał badawczy pozwala również zaobserwować, że część grupy (9 osób) charakteryzuje postawa swoistej obojętności wobec popełnianych błędów na zajęciach z języka francuskiego, np.:

W ogóle nie przywiqzuję uwagi do popełnianych przez siebie błędów i trudno mi się na ten temat wypowiadać. [S1]

i tylko niektórzy respondenci (8 osób) wykazują pozytywną postawę wobec błędów językowych, np.:

Błędy sq nieuniknione i jak nie będę ich popełniat, to się nigdy nie nauczę tego języka [francuskiego]! [S28]

Popełniane błędy pomagaja mi zrozumieć, nad czym jeszcze muszę popracować $\mathrm{w}$ danym rozdziale. [S62]

Analiza dotychczasowych danych pokazuje, że dla ankietowanej grupy błąd stanowi źródło raczej negatywnych doświadczeń. Co więcej, odpowiedzi na kolejne pytanie ([P3] Czy i w jaki sposób wykorzystuje Pan/Pani swoje błędy językowe w rozwijaniu swoich umiejętności w zakresie języka francuskiego?) świadczą o tym, że studenci rzadko odwołują się do swoich błędów i nie wykorzystują ich w świadomy sposób w celu rozwijania umiejętności językowych. Taką postawę deklaruje 38 [61\%] ankietowanych. W przypadku pozostałych 
osób, dostarczone przez nich opinie świadczą o tym, że starają się w mniejszym lub większym zakresie wykorzystywać popełnianie przez siebie błędy i włączyć je do regularnej nauki:

Staram się zapamiętywać swoje błędy i ich poprawne formy, ale nie zawsze mi to wychodzi i potem żałuję, że ich nie pamiętam, a wiem, że już taki bład gdzieś mi się przytrafił. [S5]

Staram się notować poprawione przez nauczyciela błędy i później układam sobie z nimi zdania. [S62]

Jak coś mam źle np. w wypracowaniu, to przepisuję całe zdanie, żeby lepiej zapamiętać poprawnq formę. [S55]

Przepisuję to, co miałam źle w zdaniu i tak się uczę poprawnej formy. [S47]

Przytoczone przykłady świadczą o dosyć ubogim repertuarze technik stosowanych przez ankietowanych w pracy nad wyeliminowaniem popełnianych błędów. Najczęstszą, jaką wskazują studenci, jest przepisywanie niepoprawnych form i ich zastępowanie poprawną wersją, a w przypadku wypowiedzi ustnych - zapamiętywanie lub notowanie wskazanych przez nauczyciela błędów.

Odpowiedzi udzielone na kolejne pytanie ([P4] Na jakie błędy językowe popetniane przez siebie na zajęciach z języka francuskiego zwraca Pan/Pani szczególnq uwagę i dlaczego?) pozwoliły poznać opinię respondentów na temat tego, na jaki rodzaj błędów zwracają szczególną uwagę. Analiza zebranego materiału pokazała, że w przypadku wypowiedzi ustnych studenci koncentrują się przede wszystkim na błędach gramatycznych (41\% odpowiedzi) oraz leksykalnych (40\% odpowiedzi). Te ostatnie są również często traktowane przez ankietowanych jako główne przeszkody skutecznej komunikacji:

To, co najważniejsze, to słownictwo, bo bez niego nie można się porozumieć. [S3]

Przede wszystkim, zwracam uwagę na leksykę, uważam, że ona jest najważniejsza w komunikacji. [S17]

Najważniejsze sq słówka i to na nie zwracam szczególnq uwagę, gramatyka jest na drugim miejscu. [S39]

W przypadku wypowiedzi pisemnych studenci zdecydowanie podkreślają dbałość o formę i znaczną koncentrację na eliminowaniu błędów gramatycznych - taką opcję wskazało prawie $69 \%$ badanych, np.

W mówieniu staram się przede wszystkim pracować nad błędami leksykalnymi a w wypracowaniach nad gramatykq. [S32] 
Piszqc, koncertuję się na przede wszystkim na formie wypowiedzi i na błędach gramatycznych. [S27]

W ostatnim pytaniu ([P5] Co uważa Pan/Pani za głównq przyczynę popełnianych przez siebie błędów na zajęciach z języka francuskiego?) ankietowani zostali poproszeni o wskazanie głównych źródeł popełnianych przez siebie błędów. Wśród udzielonych odpowiedzi można było wyróżnić kilka dominujących kategorii, które zostały przedstawione na wykresie nr 2 .
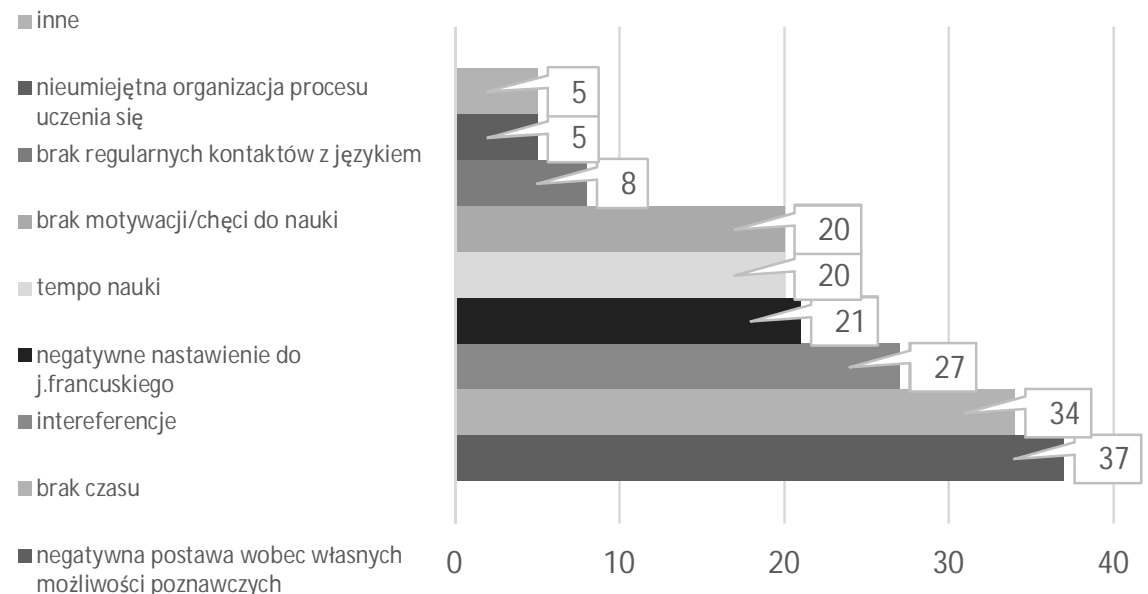

Wykres 3: Główne źródła popełnianych błędów w nauce języka francuskiego w opinii respondentów [\%].

Za główne przyczyny popełnianych przez siebie błędów w nauce języka francuskiego studenci uznają między innymi:

- negatywne nastawienie do własnych możliwości poznawczych [37\%], np.:

Nie jestem w stanie opanować tych wszystkich form. [S9]

Nie potrafię zapamiętać wszystkich poprawnych form i ciągle popełniam te same błędy. [S11]

Nie rozumiem wszystkich zasad i to mi bardzo przeszkadza łączyć je ze sobq, jak coś mówię albo piszę [S20]

- brak czasu [34\%], np.:

Nie mam wystarczajqqco dużo czasu na naukę francuskiego [S13]

Brak czasu - to mój największy wróg!" [S30] 
- interferencje, szczególnie te związane ze znajomości języka angielskiego [27\%]:

M ylq mi się formy angielskie z francuskimi. [S60]

M yślę po angielsku i te zasady mi przeszkadzaja, jak mam użyć francuskiego [S41]

- negatywne nastawienie do języka francuskiego [21\%], np.:

To przez to, że francuski jest trudny i nigdy nie będę mówić jak Francuz. [S34]

Wszystko w tym języku [francuskim] jest pozbawione jakiejkolwiek logiki. Angielski był o wiele łatwiejszy! [S1]

- tempo nauki [20\%]:

Za szybko przerabiamy materiałi nie nadq̨żam przyswoić w szystkich poprawnych form [S50]

Nie ma za dużo czasu na zapamiętanie wszystkich form na zajęciach a w domu nie zawsze udaje mi się je powtórzyć. [S19]

- brak motywacji i/lub chęci do nauki [20\%], np.:

Czasami po prostu mi się nie chce uczyć tych wszystkich reguł. [S19]

Ogólnie to chyba zniechęcenie do nauki języka francuskiego, nie podoba mi się już tak bardzo jak na poczqtku i nie chce mi się uczyć. [S6].

Pozostałe opinie studentów, wskazujące między innymi na upatrywanie przyczyn swoich błędów w braku regularnych kontaktów z językiem [8\%] czy nieumiejętności organizacji własnej nauki [5\%], stanowiły mniej popularne kategorie odpowiedzi.

\subsection{Dyskusja}

Analiza pozyskanych danych dostarczyła cennych informacji na temat percepcji błędu przez ankietowaną grupę studentów.

Ogólnie rzeczujmując, opinie respondentów świadczą raczej o dość sceptycznym podejściu do błędu i jego pozytywnej roli w nauce języka obcego. Jak mogliśmy zaobserwować, zdecydowana większość ankietowanych wykazuje negatywne nastawienie do błędu językowego (ponad 70\%). Tego rodzaju postawa znacząco kontrastuje z ogólnie przyjętym przekonaniem badaczy co do pozytywnej 
roli błędu i korekty językowej w procesie uczenia się. Co więcej, odpowiedzi ankietowanych dowodzą, że nie tylko nie potrafią wykorzystać swoich błędów w konstruktywny sposób, na co może także wpływać poświadczona w ich wypowiedziach ograniczona wiedza z zakresu technik poprawiania błędów, lecz w wielu wypadkach starają się ich unikać, wskazując przy tym na nierzadko odczuwany lęk przed ich popełnieniem lub przed „ośmieszeniem się". Na podobne wnioski w swoich badaniach zwracają uwagę specjaliści zajmujący się problematyką lęku językowego (por. Horwitz, i in., 1986; Maclntyre i Gardner, 1989; M aclntyre, 1999; Piechurska-Kuciel, 2011; Young, 1991).

Warto przypomnieć, że badania zostały przeprowadzone wśród osób dorosłych (średnia wieku - 20 lat), które na studiach rozpoczęły naukę kolejnego języka obcego, po języku polskim - ojczystym oraz języku angielskim pierwszym języku obcym. Czynniki te mogą mieć dosyć istotny wpływ na reprezentowaną przez nich postawę wobec błędu językowego. Dorosły wiek nie sprzyja właściwym dla młodszych grup uczniów postawom naturalnej akceptacji błędu oraz otwartości na otrzymywane ze strony nauczyciela korygujące informacje zwrotne (por. Bogaards, 1998; Komorowska, 2011); mogą do tego także dochodzić problemy związane z tzw. "językową przenikalnością ego", utożsamianą przez badaczy z "gotowością do eksponowania swojej niedoskonałości w posługiwaniu się danym językiem, narażania się na śmieszność wskutek niezręcznych, nieporadnych zachowań językowych" (Kurcz, 2007: 123). I choć problem pokonywania ograniczeń i przełamywania barier komunikacyjnych może dotyczyć każdej grupy wiekowej, to wydaje się, że stosunkowo często dotyka on dorosłych uczących się, którym o wiele trudniej jest wyjść poza granice swojego dotychczasowego językowego ego. Ponadto, już sam fakt bycia poprawianym może u niektórych uruchamiać wewnętrzne mechanizmy obronne i zakłócać tym samym odbiór otrzymywanej korekty językowej. Jak pokazały badania, w celu uniknięcia takich sytuacji, część osób może mniej lub bardziej świadomie unikać wypowiedzi, których poprawność budzi ich wątpliwości i tym samym nie narażać się na popełnienie błędu, a przez to ograniczać okazje do praktykowania nowo poznawanych struktur językowych. Przykłady tego rodzaju działań, niestety, mogliśmy zaobserwować w zebranym materiale badawczym.

Na brak tolerancji wobec błędu wśród uczących się czy wręcz poczucie lęku przed jego popełnieniem mogą także, paradoksalnie, wpływać ich uprzednie pozytywne doświadczenia językowe, w tym sensie, że osiągnięte już wysokie kompetencje w pierwszym języku obcym (w przypadku ankietowanej grupy był to język angielski) i posługiwanie się nim w stopniu (prawie) perfekcyjnym mogą automatycznie przenosić się na tak samo wysokie oczekiwania wobec poziomu produkowanych przez nich komunikatów w języku francuskim. W konsekwencji, 
konieczność przyjęcia statusu użytkownika o kompetencjach niepełnych, nieunikniona przynajmniej na początkowych etapach nauki języka, może rzutować na postawę wobec popełnianych błędów i rodzić niechęć do ich akceptacji. Taką sytuację mogliśmy także zaobserwować w zebranym przez nas materiale badawczym, gdzie znaleźć można było opinie wskazujące na odczuwany przez niektórych studentów wstyd, iż przy tak dobrej znajomości języka angielskiego zdarza im się popełniać „tyle błędów po francusku”, zupełnie jakby zapomnieli już o tym, ile czasu poświęcili na osiągnięcie aktualnych kompetencji w języku angielskim.

\section{Podsumowanie}

Wyniki przeprowadzonych badań skłaniają do następujących refleksji. Przede wszystkim należy stwierdzić, że choć aktualne meto dy nauczania/uczenia się języków obcych traktują błąd jako zjawisko użyteczne dla rozwoju językowych kompetencji komunikacyjnych, okazuje się, że sami uczący się mogą podchodzić do niego w sposób negatywny. Szczegółowa analiza opinii pozyskanych od osób rozpoczynających naukę drugiego języka obcego na poziomie kształcenia uniwersyteckiego pokazała, że postrzegają one błąd jako zjawisko niepożądane czy wręcz szkodliwe dla ich rozwoju językowego. Na taką postawę mogą wpływać zarówno ich wcześniejsze doświadczenia językowe oraz związane z nimi nawyki uczeniowe, jak i różnego typu czynniki afektywne. W konsekwencji, proponowane na zajęciach drugiego i kolejnych języków obcych formy pracy mogłyby zostać urozmaicone między innymi takimi ćwiczeniami i zadaniami językowymi, które pozwalałyby uczącym się zaakceptować obecność błędu w procesie uczenia się oraz korzystać z niego w bardziej świadomy i efektywny sposób w pracy nad rozwojem własnych umiejętności językowych. Działania te mogłyby stanowić pierwszy, choć oczywiście nie jedyny, krok do tego, aby dla dorosłych uczących się „błąd był tylko błędem, a więc nie źródłem frustracji, lecz raczej sukcesu" (Vester, 2006: 178).

\section{BIBLIOGRAFIA}

Arnold J. (2006), Comment les facteurs affectifs influencent-ils l'apprentissage d'une langue étrangère? (w) „Revue de didactologie des langues-cultures et de lexiculturologie", 144, str. 407-425.

Bedard E. M aurais J. (red.) (1983), La norme linguistique. Québec: Conseil de la langue française.

Bertrand O., Schaffner I. (red.) (2010), Quel français enseigner ? La question de la norme dans l'enseignement/apprentissage. Paris: Éditions de l'École Polytechnique. 
Bogaards P. (1998), Aptitude et affectivité dans l’apprentissage des langues étrangères. Paris: Hatier.

Besse H., Porquier R. (1991), Grammaire et didactique des langues étrangères. Paris: Crédif-Hatier.

Germain C. (1993), Évolution de l'enseignement des langues: 5000 ans d'histoire. Paris: Clé International.

Chomicz-Jung K. (1990), Norma glottodydaktyczna i jej rola w procesie glottodydaktycznym (w) „Przegląd Glottodydaktyczny”, nr 11, str. 21-38.

Chomicz-Jung K. (1985), Glottodydaktyczna ewaluacja błędu językowego (w) Grucza F. (red.), Lingwistyka, glottodydaktyka, translatoryka. Warszawa: Wydawnictwo Uniwersytetu Warszawskiego, str. 153-158.

Corder P. (1967) [1980a], Que signifient les erreurs des apprenants ? (w) „Langages", 57, str. 9-15.

Corder P. (1971) [1980b], Dialectes idiosyncrasiques et analyse d'erreurs. "Langages", 57, str. 17-28.

Cuq J.-P., Gruca I. (2005), Cours de didactique du français langue étrangère et seconde. Grenoble: PUG.

Ellis R. (2009), Corrective feedback and teacher development (w) „L2 Journal”, nr 1, str. 3-18.

Germain C. (1993), Évolution de l'enseignement des langues: 5000 ans d'histoire. Paris: Clé International.

Hadji C. (2012), Faut-il avoir peur de l'évaluation? Bruxelles: Groupe De Bœck s.a. Horwitz E. K., Horwitz M. B., Cope J. (1986), Foreign language classroom anxiety (w) „The Modern Language Journal”, nr 70 (2), str. 125-132.

Huver E., Springer C. (2011), L'évaluation en langues. Paris: Les Éditions Didier. Komorowska H. (red.), (2011), Nauka języka obcego w perspektywie ucznia. Warszawa: Oficyna Wydawnicza Łośgraf.

Kurcz I. (red.) (2007), Psychologiczne aspekty dwujęzyczności. Gdańsk: GWP.

Larruy M. M. (2003), L'interprétation de l'erreur. Paris: CLE International/VUEF.

Lewicka-M roczek E. (2009) Błqd językowy na lekcji języka obcego. Sposoby reagowania i terapii (w) Komorowska H. (red.) Skuteczna nauka języka obcego. Struktura i przebieg zajęć językowych. Warszawa: Wydawnictwo CODN, str. 25-36.

Lyster R., Ranta L. (1997), Corrective feedback and learner uptake: Negotiation of form in communicative classrooms (w) "Studies in Second Language Acquisition", nr 19 (1), str. 37-66.

M aclntyre P. D. (1999), Language Anxiety: A Review of the Research for Language Teachers (w) Young D. J. (red.), Affect in foreign language and 
second language learning. A practical guide to creating a low-anxiety classroom. Boston: M cGraw-Hill, str. 24-45.

M aclntyre P. D., Gardner R. C. (1989), Anxiety in second-language learning: toward a theoretical clarification (w) „Language Learning", nr 39 (2), str. 251-275. M iodek J. (2001), 0 normie językowej (w) Bartmiński J. (red.), Współczesny język polski. Lublin: Wydawnictwo UMCS, str. 73-83.

Mory E. H. (2004), Feadback reasearch revisited. (w) Jonanssen D. (red.), Handbook of research on educational communications and technology. M ahwah: Erlbaum Associated, str. 745-783.

Pawlak M. (2013), Czynniki warunkujqce występowanie i skuteczność korekty błędów językowych podczas mówienia (w) Pawlak (red.), Mówienie w języku obcym: skuteczne uczenie się, nauczanie i ocenianie. Poznań - Kalisz - Konin: Wydawnictwo UAM i PWSZ w Koninie, str. 305-326.

Pawlak M . (2012), Error Correction in the Foreign Language Classroom: Reconsidering the Issues. Poznań-Kalisz-Konin: Wydział Pedagogiczno-Artystyczny UAM .

Piechurska-Kuciel E. (2011), Trudności w rozwijaniu sprawności interakcyjnych rola lęku językowego (w) Komorowska H. (red.), Nauka języka obcego w perspektywie ucznia. Warszawa: Oficyna Wydawnicza Łośgraf, str. 239-258.

Półtorak E. (2019), Zjawisko lęku językowego w procesie nauczania-uczenia się języka francuskiego jako drugiego języka obcego (w) Bielak M. I, Krawczyk M , M aliszewski W. (red.), Wymiary instytucjonalnej przestrzeni komunikacyjnej. Toruń: Wydawnictwo Adam Marszałek (w druku).

Półtorak E. (2018), Nauczanie języków obcych w dobie nowych technologii: multimedialne narzędzia dydaktyczne a proces pozyskiwania/przekazywania informacji zwrotnych (w) Gabryś-Barker D., Kalamarz R., Stec M. (red.), Materiały i media we współczesnej glottodydaktyce: wybrane zagadnienia. Katowice: Wydawnictwo Uniwersytetu Śląskiego, str. 119-133.

Półtorak E. (2015), L'impact des nouvelles technologies sur les pratiques évaluatives en langues vivantes. Katowice: Wydawnictwo Uniwersytetu Śląskiego.

Rada Europy (2003), Europejski system opisu kształcenia językowego. Warszawa: Wydawnictwo CODN.

Rey A. (1974), La norme. Quel français enseigner ? (w) „FIPF”, 10-11, str. 47-53. Smuk M. (2016), Od cech osobowości do kompetencji savoir-être - rozwijanie samoświadomości w nauce języków obcych. Lublin - Warszawa: Wydawnictwo Werset.

Siouffi G., Steuckardt A. (red.) (2007), Les linguistes et la norme. Aspects normatifs du discours linguistique. Berne: Peter Lang.

SzulcA. (1984), Podręczny słownik językoznawstwa stosowanego. Warszawa: PWN. Tagliante C. (2005), L'évaluation et le Cadre européen commun. Paris: CLE International/SEJER. 
Tardieu C. (2008), La didactique des langues en 4 mots clés : Communication, culture, méthodologie, évaluation. Paris: Ellipses Éditions M arketing S.A. Vester F. (2006), M yślenie, uczenie się, zapominanie. Co się dzieje w naszej głowie? Jak uczy się mózg? Dlaczego niekiedy zawodzi? Bydgoszcz: Wydawnictwo Polsko-Niemieckie "Glossarium".

Wilczyńska W., M ichońska-Stadnik A. (2010), M etodologia badań w glottodydaktyce. Wprowadzenie. Kraków: Avalon.

Young D. J. (1991), Creating a Low-Anxiety Classroom Environment: What Does Language Anxiety Research Suggest? (w) „The M odern Language Journal", 75(4), str. 426-439.

Zawadzka E. (2004), Nauczyciele języków obcych w dobie przemian. Kraków: Oficyna Wydawnicza "Impuls".

Zbróg P. (red.) (2018), Wybrane aspekty badań nad normq językowq. Kraków: Wydawnictwo LIBRON. 